Research Article

\title{
Dissimilarity of absorbing internal radiation dose of 99mTc- diethylenetriaminepentacetate among male, female and international committee for radiation protection - 53 recommended data
}

\author{
Md. Nazrul Islam ${ }^{1}$, Debendra Nath Roy $^{2}$
}

\begin{abstract}
${ }^{1}$ Department of Applied Physics, Electronics and Communication Engineering, Islamic University, Kushtia, Bangladesh, ${ }^{2}$ Department of Pharmacy, Jessore University of Science and Technology, Jessore-7408 Bangladesh
\end{abstract}

Received: 20 June 2016 Accepted: 08 July 2016

*Correspondence to: Mr. Md. Nazrul Islam, Email: nazrul.jstu@gmail.com

Copyright: () the author(s), publisher and licensee Medip Academy. This is an openaccess article distributed under the terms of the Creative Commons Attribution NonCommercial License, which permits unrestricted noncommercial use, distribution, and reproduction in any medium, provided the original work is properly cited.

\begin{abstract}
Background: Radioisotope tomography is a form of medical imaging of the kidneys that uses radiolabelling. The two most common radiolabelled pharmaceutical agents used are Tc99m-MAG3 (MAG3 is also called mercaptoacetyltriglycine) and Tc-99m-DTPA (diethylenetriaminepentacetate). Tc-99m-DTPA is filtered by the glomerulus and used to measure the glomerular filtration rate and is the second most commonly used renal radiopharmaceutical, primarily because it is the least expensive. The main objective of the present study was to obtain the bio-kinetic data of organ activity as well as organ absorbed dose of Tc99m-DTPA for single photon emitters.

Methods: We have carried out a method to obtain accurate organ activity with single photon emission computed tomography (SPECT). Tc-99m-DTPA radiopharmaceutical medicine was used as single photon emitters and we have demonstrated effective decay method and conventional method to obtain accurate organ (seven) activity with single photon emission computed SPECT. The observed organ activity is due to the Tc99m-DTPA is obtained and the data is compared among male, female and ICRP (international committee for radiation protection)-53 recommended data as well.

Results: The outcome of study revealed that, dose absorbed power of male is greater than female, so in nuclear medicine centre absorbed doses should be estimated separately both for male and female for more proper treatment opportunity. It is also observed that there is no good agreement of absorbed dose values among male, female and ICRP-53 recommended data.

Conclusions: Our achieved result is due to the extreme variation in food values and fundamental needed elements are certainly different between Bangladeshi peoples and foreigners. In case of foreigner's it is almost equal for male and female, whereas for Bangladeshi male and female it is certainly different.
\end{abstract}

Keywords: Radiopharmaceuticals, Nuclear medicine, Organ activity, Dose

\section{INTRODUCTION}

Nuclear medicine is a very useful technique to diagnose various disease of human. Up to date new methods and new radiopharmaceuticals are continually being introduced in nuclear medicine. As the progressive use of radiopharmaceuticals in nuclear medicine it is also necessary to establish the magnitude of the risk involved with the use of radiation to compare with the benefit that can be obtained from these diagnostic procedures, so that the patient can obtained a real benefit and the results will be better than that obtained by other diagnostic modalities. Knowledge of the radiation absorbed doses will enable the clinician to compare the benefit using radio nuclides with the potential risk from the radiation. At the same time it will be helpful to determine the maximum amount of activity, which can safely be administered to a patient to provide the desired medical information. To know the risk of administered radiopharmaceuticals, the measurement of distributed radio activities and the estimation of absorbed dose in the organs are termed as internal dosimetry. ${ }^{1-6}$ The present time there is an increased interest in evaluating the absorbed dose delivered to patients by 
radiopharmaceutical. Recently, about 120 radiopharmaceuticals used in nuclear medicine, has been published by ICRP-53 publication. ${ }^{7}$ The internal absorbed dose is measured by the MIRD (medical internal radiation dose) method. ${ }^{8}$

Measurement of radioactivity in human organs is a major problem in internal radiation dosimetry. At present the data of internal absorbed dose is not so accurate due to inadequate data regarding the bio-distribution of radio chemicals in the body. ${ }^{9}$ The conventional techniques used in the purpose are the extrapolation of animal data to human, calculations based on the mathematical biokinetic models and direct measurements. ${ }^{10-27}$ Among this method direct measurements can provide activity distributions with less biological assumption and NCRP (national council of radiation protection has emphasized on direct measurements of the radio activities distributed in human. ${ }^{9}$

Single photon emission computed tomography (SPECT) and positron emission tomography (PET) is a new imaging modality in nuclear medicine that provides regional as well as global information about physiology or chemistry within various body organs. For positron emitters although a very few direct measurements of organ activities have been done for dosimetric purpose for single photon emitters so far no experimental data is available ICRP-53., 26,29,30 In the report of NCRP9 although some guidelines to measure the radioactivity with the diagnostic instruments (PET, SPECT and gamma camera) are given, it becomes difficult for the nuclear medicine centres to obey those guidelines only for dosimetric purposes due to their busy schedule. Since from the beginning both male and female are taking the treatment from nuclear medicine centre and ICRP recommended the absorbed dose only for male but not female, the absorbed dose for female is an important thing. However, in this study, absorbed dose for both male and female has been made and compared those with the ICRP-53 recommended absorbed dose. ${ }^{7}$ Definitely, this inter comparison of results between male and female will be helpful to assess the accuracy of the dose administrated in the patient. For dose calculation we use two methods, one is effective decay method and another is conventional method (normal calculation). As the $99 \mathrm{~m}$ Tc-compounds are widely used in nuclear medicine, we have used $99 \mathrm{~m}$ Tc-DTPA. Finally using the present experimental data of cumulated activity, the absorbed dose has been estimated for seven target organs by the MIRD method. ${ }^{31}$ Also we compare the results of dose calculation with ICRP-53 recommended data.

\section{METHODS}

\section{Calculation of absorbed dose}

In the MIRD method the organs were classified into source organs in which radiopharmaceuticals accumulated and target organs to which radiation from a source organ is penetrated. ${ }^{31}$ The absorbed dose of a target organ defined by Loevinger et al can be expressed as: $^{32}$

$$
\bar{D}(r k)=\sum_{h} \tilde{A}_{h} S(r k \leftarrow r h)
$$

Where $\tilde{A}_{h}$ is the cumulated activity of the $\mathrm{h}_{\mathrm{th}}$ source organ and $\mathrm{S}\left(\boldsymbol{r}_{K} \leftarrow \boldsymbol{r}_{h}\right)$ is the absorbed dose in the k-th target organ per unit cumulated activity of the $h_{t h}$ source organ, i. e. S-value. The absorbed doses for various radiopharmaceuticals presented in this thesis were calculated using (1). In the dose calculation procedure seven organs were considered as the target organs.

The Cumulated activity $\tilde{A}_{h}$ in a source organ or tissue $\mathrm{h}$, depends on the administered activity,

$\mathrm{A}_{\mathrm{o}}$ is the physical half-life and $\lambda$ is the bio-kinetics of the radiopharmaceuticals. $\widetilde{A}_{h}$ is obtained by integrating the time dependent activity:

$\tilde{A}_{h}=\int_{0}^{\infty} A_{h}(t)$

Where $A_{h}(\mathrm{t})$ is the activity at time $\mathrm{t}$ in the source organ or tissue considered.

\section{Cumulated activity in the remainder of the body}

The cumulated activity of the remainder of the body can be calculated according to the available data as follows.

In the first approach the residence time for the remainder of the body can be calculated if we know the retention function for the total body. The retention function for total body can be derived from direct measurements by using a total body counting or from measurements of urinary (and/or focal) excretion. It can be expressed as a sum of exponential.

$$
A_{T B}(t)=\sum_{i} A_{i} e^{-k_{i} t}
$$

And, the residence time for the remainder of the body is obtained by the following equation:

$$
\tau_{R B}=1.443 F_{R B} \sum_{i} A_{T B i} T_{T B i}
$$

Where $\mathrm{A}_{\mathrm{TBi}}$ and $\mathrm{T}_{\mathrm{TBi}}$ are the intercept and the effective half-life of the exponential component for total body, and $F_{R B}$ is the fraction of the injected activity retained in the 
remainder of the body. In the second approach, the cumulated activity for the remainder of the body can be calculated as the difference between the cumulated activity in total body (TB) and the sum of the individual cumulated activity in each source organ $\left(\mathrm{h}_{\mathrm{i}}\right)$ as:

$$
\tilde{A}_{R B}=\widetilde{A}_{T B}-\sum_{i} \tilde{A}_{h i}
$$

\section{Cumulated activity calculations}

In eight source organs typical time activity curves were obtained from measurements with whole body SPECT. Those organs were brain, thyroid, heart, liver, stomach, kidney, bladder and remainder of the body. The time activity curves were fitted with the function used by Jones et al as follows: ${ }^{11}$

$$
\tilde{A}=k_{1} \int_{0}^{\infty} e^{-K_{2} t} d t+k_{3} \int_{0}^{\infty} e^{-K_{4} t} d t
$$

Where $\mathrm{k}_{2}$ and $\mathrm{k}_{4}$ are the intercepts and $\mathrm{k}_{1}$ and $\mathrm{k}_{3}$ are biological elimination constant, including physical decay constant. This method is denoted as effective decay method. The cumulated activity of the remainder of the body was calculated according to the suggestion of the Ph.D. thesis of Mejia et al. ${ }^{33}$ To obtain the activity of the remainder of the body a free hand region of interest
(ROI) was drawn on each whole body image and the total activity was measured. Sum of the activity of seven source organs (brain, thyroid, heart, liver, stomach, kidney and bladder) and the activity of urine were subtracted from the total activity of the whole body, which gives the activity of the remainder of the body.

As the activity of radioactive substances cannot stay in the infinite time, so there are some errors in our experimental values. To overcome these problems we considered a new calculation method (normal calculation) which defined as conventional method.

$\tilde{A}(t)=\left(k_{1} k_{4}+k_{2} k_{3}\right) / k_{2} k_{4}$

\section{RESULTS}

From this study it was found that, the administration of Tc99m-DTPA radiopharmaceuticals have absorbed dose of Milli Gray/Mega Becquerel (mGy/MBq) per unit organ (seven) activity of male patients in of brain, stomach, heart, kidney, lung, thyroid and bladder and the observed mean value of $4.41 \mathrm{E}-03,1.89 \mathrm{E}-03,4.37 \mathrm{E}-03$, $3.95 \mathrm{E}-03,6.93 \mathrm{E}-03,4.13 \mathrm{E}-03$ and $6.44 \mathrm{E}-03$ respectively as shown in Table 1. Likewise, absorbed dose per unite activity administrated of ${ }^{99 \mathrm{~m}}$ Tc-DTPA in female patients for above mentioned seven organ were $2.71 \mathrm{E}-03,3.24 \mathrm{E}$ $03,2.76 \mathrm{E}-03,1.58 \mathrm{E}-03,3.66 \mathrm{E}-03,2.51 \mathrm{E}-03$ and $1.00 \mathrm{E}-$ 03 shown in Table 2.

Table 1: Absorbed dose per unite activity administrated of 99mTc-DTPA (mGy/MBq) for male (nuclear medicine centre, Bogra).

\begin{tabular}{|llllll|}
\hline Organs & Patient-1 & Patient-2 & Patient-3 & Patient-4 & Average \\
\hline Brain & $2.84 \mathrm{E}-03$ & $3.72 \mathrm{E}-03$ & $7.59 \mathrm{E}-03$ & $3.49 \mathrm{E}-03$ & $4.41 \mathrm{E}-03$ \\
\hline Stomach & $1.05 \mathrm{E}-03$ & $1.14 \mathrm{E}-03$ & $1.25 \mathrm{E}-03$ & $8.55 \mathrm{E}-04$ & $1.89 \mathrm{E}-03$ \\
\hline Heart & $7.61 \mathrm{E}-03$ & $2.15 \mathrm{E}-03$ & $2.36 \mathrm{E}-03$ & $5.82 \mathrm{E}-03$ & $4.37 \mathrm{E}-03$ \\
\hline Kidney & $3.77 \mathrm{E}-03$ & $6.52 \mathrm{E}-03$ & $2.05 \mathrm{E}-03$ & $3.13 \mathrm{E}-03$ & $3.95 \mathrm{E}-03$ \\
\hline Lung & $6.25 \mathrm{E}-03$ & $8.16 \mathrm{E}-03$ & $7.52 \mathrm{E}-04$ & $4.87 \mathrm{E}-03$ & $6.93 \mathrm{E}-03$ \\
\hline Thyroid & $1.36 \mathrm{E}-03$ & $2.33 \mathrm{E}-03$ & $8.25 \mathrm{E}-05$ & $9.51 \mathrm{E}-03$ & $4.13 \mathrm{E}-03$ \\
\hline Bladder & $3.78 \mathrm{E}-03$ & $6.08 \mathrm{E}-03$ & $2.49 \mathrm{E}-04$ & $2.07 \mathrm{E}-04$ & $6.44 \mathrm{E}-03$ \\
\hline
\end{tabular}

Table 2: Absorbed dose per unite activity administrated of 99mTc-DTPA (mGy/MBq) for female (nuclear medicine center, Bogra).

\begin{tabular}{|llllll|}
\hline Organs & Patient-1 & Patient-2 & Patient-3 & Patient-4 & Average \\
\hline Brain & $1.73 \mathrm{E}-03$ & $5.31 \mathrm{E}-03$ & $2.90 \mathrm{E}-04$ & $3.54 \mathrm{E}-03$ & $2.71 \mathrm{E}-03$ \\
\hline Stomach & $1.59 \mathrm{E}-03$ & $5.52 \mathrm{E}-03$ & $5.56 \mathrm{E}-03$ & $3.02 \mathrm{E}-04$ & $3.24 \mathrm{E}-03$ \\
\hline Heart & $5.18 \mathrm{E}-04$ & $5.27 \mathrm{E}-04$ & $5.27 \mathrm{E}-03$ & $4.73 \mathrm{E}-03$ & $2.76 \mathrm{E}-03$ \\
\hline Kidney & $1.94 \mathrm{E}-03$ & $2.05 \mathrm{E}-04$ & $2.06 \mathrm{E}-03$ & $2.13 \mathrm{E}-03$ & $1.58 \mathrm{E}-03$ \\
\hline Lung & $2.56 \mathrm{E}-04$ & $7.09 \mathrm{E}-03$ & $1.47 \mathrm{E}-03$ & $7.83 \mathrm{E}-03$ & $3.66 \mathrm{E}-03$ \\
\hline Thyroid & $2.00 \mathrm{E}-03$ & $1.91 \mathrm{E}-03$ & $4.19 \mathrm{E}-03$ & $1.95 \mathrm{E}-03$ & $2.51 \mathrm{E}-03$ \\
\hline Bladder & $2.43 \mathrm{E}-04$ & $1.37 \mathrm{E}-03$ & $1.38 \mathrm{E}-03$ & $8.66 \mathrm{E}-04$ & $1.00 \mathrm{E}-03$ \\
\hline
\end{tabular}


Table 3: Comparison among the experimental values of the absorbed doses of 99mTc-DTPA (mGy/MBq) of male, female and the result of ICRP-53 recommended data.

\begin{tabular}{|llll|}
\hline \multicolumn{1}{c}{$\begin{array}{c}\text { Source } \\
\text { organs }\end{array}$} & Male & Female & ICRP-53 \\
\hline Brain & $4.41 \mathrm{E}-03$ & $2.71 \mathrm{E}-03$ & $2.78 \mathrm{E}-03$ \\
\hline Stomach & $1.89 \mathrm{E}-03$ & $3.24 \mathrm{E}-03$ & $1.30 \mathrm{E}-03$ \\
\hline Heart & $4.37 \mathrm{E}-03$ & $2.76 \mathrm{E}-03$ & $2.75 \mathrm{E}-03$ \\
\hline Kidneys & $3.95 \mathrm{E}-03$ & $1.58 \mathrm{E}-03$ & $4.40 \mathrm{E}-03$ \\
\hline Lungs & $6.93 \mathrm{E}-03$ & $3.66 \mathrm{E}-03$ & $1.00 \mathrm{E}-03$ \\
\hline Thyroid & $4.13 \mathrm{E}-03$ & $2.51 \mathrm{E}-03$ & $7.90 \mathrm{E}-03$ \\
\hline Bladder & $6.44 \mathrm{E}-03$ & $1.00 \mathrm{E}-03$ & $6.50 \mathrm{E}-03$ \\
\hline
\end{tabular}

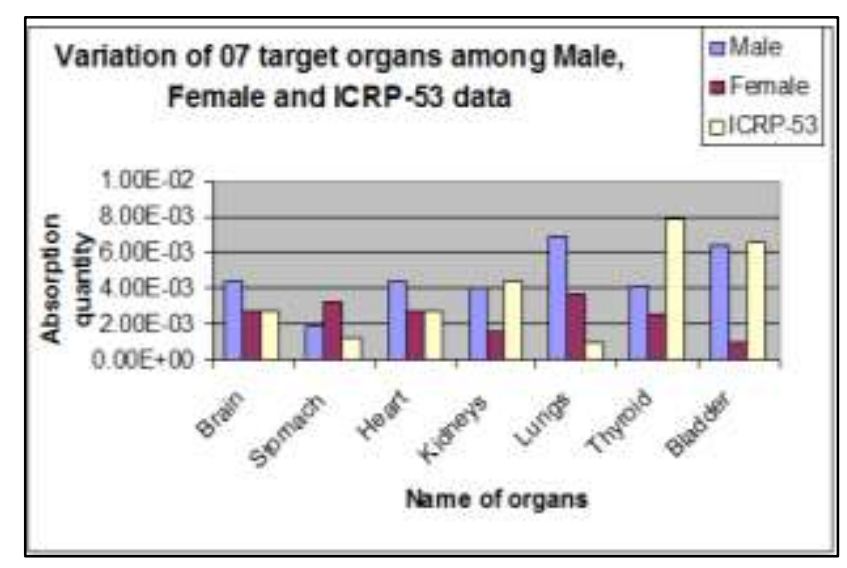

Figure 1: Radiation absorption of brain, stomach, heart, kidneys, lungs, thyroid, bladder of male and female and its comparison with ICRP-53 recommended data.

In case of the result of ICRP-53 recommended data, it was observed as $2.78 \mathrm{E}-03,1.30 \mathrm{E}-03,2.75 \mathrm{E}-03,4.40 \mathrm{E}-$ 03, 1.00E-03, 7.90E-03 and 6.50E-03 for brain, stomach, heart, kidney, lung, thyroid and bladder respectively in Comparison among the experimental values of the absorbed doses of ${ }^{99 \mathrm{~m}} \mathrm{Tc}-\mathrm{DTPA}(\mathrm{mGy} / \mathrm{MBq})$ of male and female data also presented in Table 3. However, there was a significant variation of radiation absorption observed for Tc99m-DTPA radiopharmaceuticals in brain, stomach, heart, kidneys, lungs, thyroid, and bladder of male, female and its comparison with ICRP-53 recommended data is shown in Figure 1.

\section{DISCUSSION}

Since tomography image of SPECT can provide more accurate data, we have evaluated this method to obtain bio-kinetic data as well as absorbed dose with the whole body SPECT system. Although the transmission scan, in each SPECT measurement is a prerequisite condition for attenuation correction to get the accurate emission data, due to technical limitations it was not possible to acquire the transmission data. A constant value of attenuation coefficient $(\mu=0.15$ per $\mathrm{cm})$ was used to acquire the image data. For each subject, the transmission scan can provide a $\mu$-map for the shape and position of the subject appeared in SPECT measurements, which can provide more accurate data. ${ }^{29,30}$ However, uses of a constant value of $\mu$ to the emission data will introduce some errors; as a result the organ activity as well as the absorbed doses might be suffered from the actual result. Seven organs, in this study were considered as the source organs for administration of $99 \mathrm{mTc}$-compounds. Therefore, the activity was measured for a certain time interval in calculation of the cumulated activity in source organs, no experimental data of activity were present after the last measurement; the fitting parameters provided the organ activity for an infinite time with a constant biological disappearance data. ${ }^{15,16}$

\section{CONCLUSION}

Most of the published dosimetric data in ICRP 53 have been based on the bio-kinetic model or extrapolation from animal data, in which large number of assumptions are made. Direct measurements can provide more accurate bio-kinetic data of activity as well as absorbed doses and NCRP has also emphasized on direct measurement of accurate organ activity with SPECT. Dose absorbed power of male is high, so in nuclear medicine centre absorbed doses are estimated separately for different male for more proper treatment. It is observed that there is no good agreement of absorbed dose values between the two methods. In all cases the measured values of effective decay method is about two times higher than conventional method. Therefore, there is a scope for further study with better statistic.

\section{ACKNOWLEDGEMENTS}

It is a great pleasure to express authors deepest sense of gratitude and indebtedness to Professor Dr. M. Deloar Hossain, Department of Physics, University of Rajshahi, for his kind guidance and constant encouragement throughout our research work. Authors indebted to Dr. Salim M. Answari, Director, NMC, Bogra, for not only permitting me to use the facilities of his centre but also his kind cooperation and friendly attitude was essential to perform this work. Finally, Authors wish to convey my thanks to Mr. Arman Ali, Operator, NMC, Bogra for his valuable suggestions. Authors highly grateful to his parents, brothers, sisters and nearest relatives for their inspiration, encouragement and support to carry out this thesis work.

\section{Funding: No funding sources \\ Conflict of interest: None declared \\ Ethical approval: Not required}

\section{REFERENCES}

1. Marinelli LD. Dosage determinations with radioactive isotopes. I Nucleonics. 19484(1):56. II Nucleonics. 1948;(2)5:44. 
2. Marinelli LD, Quimby EH, Hine GJ. Dosage determinations with radioactive isotopes II. Practical consideration in therapy and protection. Am J Roentgenol Radium Ther. 1948;59:260.

3. Mayneord WV. The mathematical theory of integral dose in radium therapy. Br J Radiol. 1945;18:260.

4. Loevinger R, Holt JG, Hine GJ, Brownell GL. Internally administered radioisotopes and radiation dosimetry. Academic press, New York; 1956.

5. Ellett WH, Callaman AB, Brownell GL. Gamma ray dosimetry of internal emitters. I Montecarlo calculations of absorbed dose from point source. Br J Radiol. 1964;37:45.

6. Ellett WH, Callaman AB, Brownell GL. Gamma ray dosimetry of internal emitters. I Montecarlo calculations of absorbed dose from uniform source. Br J Radiol. 1965;38:541.

7. Mird dose estimation report No. 8 Summary of current radiation dose. Estimates to normal human from $99 \mathrm{mTc}$ as sodium pertechnetate, JNM. 1976;17:74-7.

8. Loevinger R, Berman M. A schema for absorbed dose calculations for biologically-distributed redionuclides. Medical Internal Dose Committee (MIRD) pamphlet No. 1. J Nucl Med. 1968;9:Supp 11:7-14.

9. National Council on radiation Protection and measurements, NCRP report No. 83. The experimental basis for absorbed-dose calculations in medical uses of radionuclides. National council on Radiation Protection and Measurements. 7910 Woodmont Avenue, MD. 20814; 1985;6-56.

10. Brownel GL, Ackerman RH, Strauss WH. Preliminary imaging results with 18F-2-fluoro-2deoxy-D-glucose. J comput Assit Tomogr. 1980;4:473-7.

11. Jones SC, Alvi A, Christman D, Montaned I, Wolf AP, Reivich M. The radiation dosimetry of 2-[18F] fluoro-2-deoxy-D-glucose in man. $\mathrm{J}$ Nucl Med. 1982;23:613-7.

12. Harvey J, Firnau G, Garrnett ES. Estimation of the radiation dose in human due to $6-[18 \mathrm{~F}]$ fluoro-Ldopa. J Nucl Med. 1985;26:931-5.

13. Thonoor CM, Couch MW, Greer DM, Thomas KD, Williams CM. Biodistribution and radiation dosimetry of radioiodinated-SCH 23982, a potential dopamine D1 receptor imaging agent. J Nucl Med. 1988;29:1668-74.

14. Mark CW, James EC, Phillip SS, Micheal RK. Simplifying the dosimetry of carbon-11-labeled radiopharmaceuticals. J Nucl Med. 1997;38:654-60.

15. Bigler RE, Sgouros G. Biological analysis and dosimetry for 15O-labeled $15 \mathrm{O} 2, \mathrm{C} 15 \mathrm{O} 3$ and $\mathrm{C} 15 \mathrm{O}$ gases administered continuously by inhalation. J Nucl Med. 1983;24:431-7

16. Subramanaya R, Alpert NM, Hoop BJ, Brownell GL, Tavera JM. A model for regional cerebral oxygen distribution during continuous inhalation of 15O2, C15O2 and C15O. J Nucl Med. 1978:19:48.
17. Charkes ND, Makler PT, Pilips C. Studies of skeletal tracer kinetics. 1 Digital-computer solution of a fivecompartment model of $[18 \mathrm{~F}]$ fluoride kinetics in humans. J Nucl Med. 1978;19:1301-9.

18. Brihaye C, Depresseux JC, Comer D. Radiation dosimetry for bolus administration of oxygen-15water. J Nucl Med. 1995;36:651-6.

19. Jones SC, Alvi A, Christman D, Montanex I, Wolf AP, Reivich M. The radiation dosimetry of 2-[18F] fluoro-2deoxy-D-glucose in man. $J$ Nucl Med. 1982;23:613-7.

20. Mejia AA, Nakamura T, Itoh M, Hatazawa J, Masaki M, Watanuki S. Estimation of absorbed doses in human due to intravenous administration of fluorine18-fluorodeoxyglucose in PET studies. J Nucl Med. 1991;32:699-709.

21. Herzog $H$, Coenen $H H$, Kuwert $T$, Langen $J$. Feinendegen LE. Quantification of the whole-body distribution of PET radiopharmaceuticals, applied to 3-N-([18F] fluoroethyl) spiperone. Eur J Nucl Med. 1990;16:77-83.

22. Kearfott KJ. Radiation absorbed dose estimates for position emission tomography (PET): C15O. J Nucl Med. 1982;23:1031-7.

23. Deloar HM, Shidahara M, Fujiwara T, Watabe H, Narita $\mathrm{Y}$, Itoh $\mathrm{M}$, et al. Radiation absorbed dose estimates for 2-[F-18] Fluoro-2-Deoxy-D-Glucose by using whole body PET and MRI. J Nucl Med. 1998:25(6):565;74.

24. Meyer E, Yamamoto LY, Evans AC, Tyler JL, Dicsic M, Feindel W. Radiation dose to upper airways from inhaled oxygen-15 carbondioxide. J Nucl Med. 1987;28:234-9.

25. Huhi DE, Koeppe RA, Fesler JA, Minoshima S, Ackermann RJ, Carey JE, et al. In vivo mapping of cholinergic neurons in the human brain using SPET and IBVM. J Nucl Med. 1994;35:405-10.

26. Schmidt D, Langen KJ, Herzog H, Wirths J, Holschbach M, Kiwit JCW, et al. Whole-body Kinetics and dosimetry of L-3-[123I]iodo- $\alpha$ methltyrosine. Eur J Nucl Med. 1997; 24:1162-6.

27. Dey HM, Seibyl JP, Stubbns JB, Zoghbi SS, Baldwin RM, Smith EO, et al. Human biodistrihution and dosimetry of the SOECT benzodiazepine receptor radioligand iodine-123-iomazenil. J Nucl Med. 1994;35:399-404.

28. Deloar HM, Fujiwara T, Shidahara M, Nakamura T, Yamadera A, Itoh M. Development of methodology to estimate internal radiation absorbed dose in nuclear medicine. Phys Med Biol. 1999;44(2):595606.

29. Deloar HM, Nakamura T, Itih M, Fujwara T. Estimation of internal absorbed dose of L-[methyl11C] nethioine using whole body PET. EUR JNM. 1998;25:629-33.

30. Deloar HM, Fujiwara T, Shidahar M, Nakamura T, Yamadera A, Itoh $M$. Internal absorbed dose estimation by a TDL method for 18F-FDG and comparison with the dose estimates from whole body PET. Eur JNM. 1998;25:565-74. 
31. Alam M. Internal radiation absorbed dose estimation of technetium-99m radiopharmaceuticals in nuclear medicine (M. Sc. Thesis) Department of Physics, University of Rajshahi. 1999;20:593-601.

32. Loevinger R, Buidinger TF, Watson EE. MIRD primer for absorbed dose calculations. In collaboration with the MIRD committee. The Society of Nuclear Medicine, Inc. New York. 1991;21:79-89.

33. Mejia A. Internal dosimetry of positron emitting labeled radiopharmaceutical in nuclear medicine. Ph. D. Thesis, Department of Nuclear Engineering, Tohoku University, Japan; 1991;32:875-7.

Cite this article as: Islam MN, Roy DN.

Dissimilarity of absorbing internal radiation dose of $99 \mathrm{mTc}$ - diethylenetriaminepentacetate among male, female and international committee for radiation protection - 53 recommended data. Int $\mathrm{J}$ Basic Clin Pharmacol 2016;5:1239-44. 